\title{
SEX EDUCATION FOR INDIVIDUALS WITH HEARING DISABILITIES: DEVELOPMENT OF ANIMATION LEARNING MEDIA
}

\author{
Murni Winarsih ${ }^{1)}$, Lussy Dwiutami Wahyuni ${ }^{2)}$, Estik Wijayasari ${ }^{3)}$ \\ ${ }^{1}$ Special Education Study Program \\ Faculty of Educational Science Jakarta State University \\ ${ }^{2}$ Psychology Study Program Faculty of Psychology Jakarta State University \\ ${ }^{3}$ Jakarta State University \\ mwinarsih@unj.ac.id,sflussy@gmail.com,estikwijaya@gmail.com
}

\begin{abstract}
This research aims to know the opinion or responses from Special Education Teachers in Jabodetabek related to the needs of learning media about reproduction health for people with hearing disorders. The method of this research was quantitative. Data collection of this research used a questionnaire instrument that was tested on 105 teachers in 14 SLB as respondents. The samples were taking by using incidental sampling. Data analysis was in the form of descriptive for obtaining the picture about the needs of developing learning media about health reproduction for disability people with hearing disorders. The results of this research obtain most of respondents are at score $118-126$ in the amount of 44 people $(41,91 \%)$ stating agree and the least 3 people $(2,84 \%)$ stating extremely disagree. The results of the table show that 79 respondents $(75,25 \%)$ expect animation based media development for students with hearing disorders for sex learning about reproduction health. In the contrary, there are 26 respondents $(24,75 \%)$ who do not expect development on that media. The conclusion of this research which was conducted on 105 Special Needs School in Jabodetablek area, the results positively welcome the development of animation media on reproduction health for students with hearing disorders.
\end{abstract}

Keywords: animation media, reproduction health, disability with hearing disorders.

\section{Introduction}

"In the Standards for Sexuality Education in Europe the concept of holistic sexuality education is Learning about the cognitive, emotional, social, interactive and physical aspects of sexuality. Sexuality education starts early in childhood and progresses through adolescence and adulthood. It aims at supporting and protecting sexual development. It gradually equips and empowers children and young people with information, skills and positive values to understand (WHO: 2010, European Expert Group on Sexuality Education: 2015)." How to "expressing sexuality is part of the human experience, yet sexual health is often ignored in regard to persons with disabilities. Individuals with disabilities are at risk of sexual abuse and exploitation, unwanted pregnancies, and sexually transmitted diseases [2]. A person with disabilities according to the World Health Organization is defined as a condition that causes interference to a person's relationship with the environment. Meanwhile, with disabilities under Constitution of Republic of Indonesia No. 8, 2016 Article 1 is any person experiencing physical, intellectual, mental, and/or sensory limitations for a long period of time interacting with the environment can be Experiencing obstacles and difficulties to participate fully and effectively with other citizens based on the similarity of Rrights (Constitution of the Republic of Indonesia, 2016). 
Groups of disability in the community are divided into (1) Persons with physical disabilities: blind/vision barriers, deaf/hearing and speech barriers, tuna/disability; (2) intellectual disability; (3) a mental disability; and (4) the sensory disabilities. The amount of disability as the world's largest minority group is estimated to be one-tenth of the world's population and the number of children (Data centers and health information of INDONESIA, 2014). The number has increased to more than $15 \%$ of the world population [17]. $80 \%$ of the disabled are located in developing countries [20]. One of them is Indonesia with a disability of $11,580,117$ people [14]. When viewed in percentages, the number of people with disabilities experienced a significant increase from $2009-2012$ to $1.53 \%$. It is shown in the following figure:

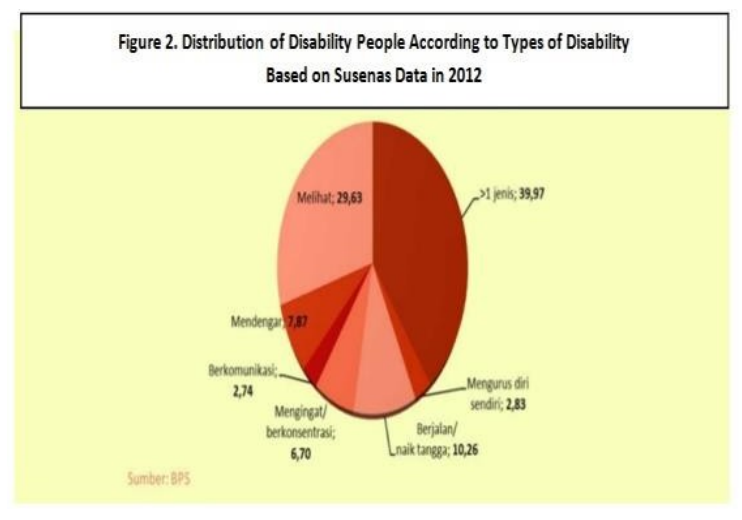

People with disabilities in Indonesia have details of the $3,474,035$ people with vision disabilities, 3,010,830 persons with physical disabilities, 2,547,626 hearing impaired people, 1,389,614 people with disabilities and 1,158,012 people with chronic disabilities [9]. According to SUSENAS data in 2012 most of the disabled are the one who experienced more than one type of limitation is $39.97 \%$, followed by the limitation of seeing $29.63 \%$, the limitation of climbing $10,26 \%$, and the limitation of hearing $7.87 \%$. This condition is shown in the following diagram: FIGURE 2.

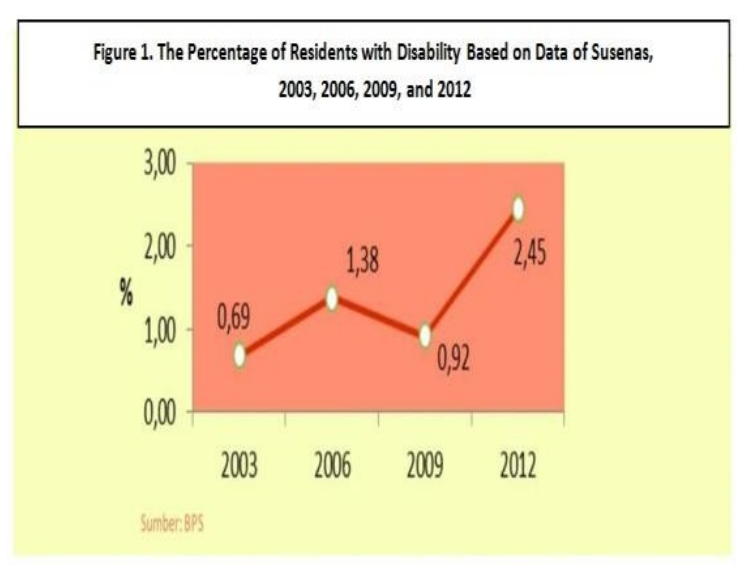

The background of the creation of the law of RI No. 8 year 2016 is for the commonalities of the rights for the disabled, but in practice still has not realized the 
similarities of these rights. One of them is inequality in providing communication, information, and education about reproductive health. Such research conducted in Ethiopia on the educational and reproductive health of the young people with disabilities said tha:

"Access to reproductive health information is often not disseminated or available to young people with disabilities. For example, in several developing countries YPWD often do not receive advice on HIVIAIDS, as the clinics are physically inaccessible, material is not available for those with visual impairments, and providers are unable to communicate in sign language (YPWD) (Kassa, Tigist Alemu.et al: 2016)."

"Sexual education regarding reproductive health is governed by the government regulation of Indonesia No. 61 year 2014, article 1, whose content is physically, mentally, and socially intact, and is not solely free from any disease or disability related to With systems, functions, and reproductive processes (government regulation of Indonesia, 2014)." Education is important, because it aims to obtain correct information about the reproduction process as well as various related factors; Among them are problems related to free sex (unprotected sexuality), the spread of sex diseases (sexual transmitted disease), pregnancy outside of marriage or unwanted pregnancy (adolescent unwanted pragnancy) [15].

Access to sexual education for reproductive health should be understood for all circles, no exception for people with hearing disabilities. In its implementation, it is hampered because there is still a stigma in society that sees the issue of sexuality and reproductive health as a taboo thing. It is reinforced by the results of a study indicating that when accessing information and services of reproductive health in Ghana; Hearing disabilities face many obstacles such as communication problems, officers ignorance, negative attitudes, and services that are not adapted to their needs ([10]. Negative perception and less unfamiliarity of society have contributed to policy abandonment and service delivery to hearing impairment [11]. . In addition, the perceptual perception of the vulnerability to sexual and reproductive health problems was primarily formed by sexual socialization of its sensing conditions. "Understanding the factors affecting the perceptions of adolescents with disabilities hearing loss about sexual health and reproduction is important primarily because the disabled sexuality is poorly understood and ignored so that put them at risk of sexual and reproductive health issues as well as exposure to sexual violence [20]."

The results of the last discovered study are in line with the data expressed by the National Commission of Human Rights. In 2016 it recorded 11,207 cases of violence in Indonesia and $35 \%$ of the women with disabilities. "It interprets every year there are 1278 cases of violence that befalls women with disabilities who, if cented almost every day, occur about 3-4 cases of violence against women with disabilities [4]."

Another form of sexual violence that befalls women with disabilities is the installation of forced contraceptives or even sterilization. Be it in institutions like school or family. They do so because they are worried that when the disability has violence or sexual intercourse, women with disabilities will be pregnant and will be troublesome for the family or school [24]. From the cases that have been delivered, the further confirms how important the disabled have the information and education related to reproductive health, especially the results of the study Romula DKK stated that health knowledge Reproduction has a negative relationship to early adolescent sexual behaviors. In other words, the higher the level of adolescent knowledge about reproductive health will make the lower the sexual behavior of the distorted or reproductive health knowledge contribute $4.3 \%$ to adolescent sexual behavior [19]. Based on various data and phenomena presented above, it is necessary to do analysis of the need for learning media about reproductive health for the disabled hearing impaired. 


\section{Theoritical Framework}

The theory used as a framework in research is the merger between the theory of reproductive health sex education with animation media and hearing disabilities. Related to education, learning Media is one of the important aspects of educating child hearing impaired to better understand the material that is delivered to them about sex education on reproductive health. "Sexuality Education aims to develop and strengthen the ability of children and young people to make conscious, satisfying, healthy and respectful choices regarding relationships, sexuality and emotional and physical health. Sexuality education does not encourage children and young people to have sex [7]." To make it easier to understand this, it is use of visual media for people with disabilities.

Visual media is one of the learning media that can be used to facilitate the disability (in this case with hearing loss) to get information and education about sex education especially about health reproduction. As the experimental study conducted by Sariyem, et al to hearing impaired students on dental hygiene resulted in the fact that animation media is very effective to increase knowledge while reducing the dental plaque subject significant [21]. Schirmer also stated that the use of multimedia such as the Internet, video phone, and email can improve the ability of hearing impaired disabilities to communicate remotely [3]. No different from the results of his study Hidayat et al said that one way to overcome the obstacles in the disabled hearing impaired is to create a multimediabased learning material that considers Learning principles for learners with hearing impairment. A series of development of audio, visual and digital technology elements to facilitate students ' learning activities with hearing loss so that their passion, quality, and achievement can be improved [8].

\section{Research Methodology}

In visual media research in the form of animation on sex learning about reproductive health for the hearing impaired use a quantitative approach. The analysis method is done in a descriptive way. The research was conducted from April-June 2019 in the special school hearing loss in the Jabodetabek area area. The instrument used questionnaire that was tested on 105 teachers in 14 SLB as respondents Test poll. The questionnaire was used to determine the response of the teacher using visual learning Media in the form of animation for reproductive health learning for special school students with hearing disabilities. The test response to the research product involved a sample of responses from 105 hearing loss teachers from 14 special schools in the greater Jakarta region with incidental sampling techniques. This poll as a means to obtain information on the implementation of sexual education of reproductive health through visual assisted learning media whether approved to be performed in learning or not. The poll measurement system uses a modified Likert scale with 5 options and its scoring calculation using the frequency distribution. 
Table of frequency distribution in research

\begin{tabular}{cccl}
$\begin{array}{c}\text { Interva } \\
\text { I Class }\end{array}$ & $\begin{array}{c}\text { Frequenc } \\
\mathbf{y}\end{array}$ & $\begin{array}{c}\text { Percentag } \\
\text { e }\end{array}$ & $\begin{array}{l}\text { Descriptio } \\
\mathbf{n}\end{array}$ \\
\hline & & & Extremely \\
& & & Disagree \\
& & & Disagree \\
\hline & & & Agree \\
& & & Extremely \\
& & & Agree \\
& & & Very \\
& & & Extremely \\
Total & 105 & 100 & Agree \\
& & & \\
\hline
\end{tabular}

\section{Results And Discussion}

\section{Results}

The data presented is data from the score related to the response to the development of animation-based media for reproductive health learning from 105 respondents in 14 special schools in the Greater Jakarta region. The statistics table description can be seen in table 1.

“Table 1. Response frequency distribution Data to development of animation based
Media for reproductive health learning in Special School in JABODETABEK area
\begin{tabular}{cccl} 
overall” \\
$\begin{array}{l}\text { Interva I } \\
\text { Class }\end{array}$ & $\begin{array}{c}\text { Frequenc } \\
\text { y }\end{array}$ & Percentag e & Descriptio n \\
\hline $\mathbf{1 0 0}-\mathbf{1 0 8}$ & 3 & 2,84 & $\begin{array}{l}\text { Extremely } \\
\text { Disagree } \\
\text { Disagree }\end{array}$ \\
\hline $\mathbf{1 0 9}-\mathbf{1 1 7}$ & 23 & 21,91 & Agree \\
\hline $\mathbf{1 1 8}-\mathbf{1 2 6}$ & 44 & 41,91 & $\begin{array}{l}\text { Extremely } \\
\text { Agree }\end{array}$ \\
\hline $\mathbf{1 2 7}-\mathbf{1 3 5}$ & 24 & 22,86 & $\begin{array}{l}\text { Very } \\
\text { Extremely } \\
\text { Agree }\end{array}$ \\
\hline $\mathbf{1 3 6}-\mathbf{1 4 4}$ & 11 & 10,48 & \\
& & $\mathbf{1 0 0}$ &
\end{tabular}

"According to table 1, the most respondents are found in the score range 118-126, which is 44 people $(41.91 \%)$ expressed agreement and at least there are 3 persons $(2.84 \%)$ expressed strongly disagree. Results of table showed that 79 respondents $(75.25 \%)$ Requires the development of animation-based media for students with impaired hearing for sexual study of reproductive health. Conversely, there are $26(24.75 \%)$ respondents who did not want the development of the learning animation media. Thus, it can be interpreted that special school teachers in the Jabodetabek area are largely positive when it will be developed animationbased 
media for reproductive health learning for hearing impaired students in the Jabodetabek area."

\section{Dimensions of Reproductive Health Program}

The data presented is data from the dimensional score of the reproductive health program from 105 respondents in 14 Special Schools in the Greater Jakarta region. Table Description Statistics can be seen in table 2.

Table 2: Frequency distribution Data for reproductive health Program for hearing loss in Special School in JABODETABEK area"

\begin{tabular}{|c|c|c|c|}
\hline $\begin{array}{l}\text { Interva } \\
\text { I Class }\end{array}$ & $\begin{array}{c}\text { Frequenc } \\
\mathbf{y}\end{array}$ & $\begin{array}{c}\text { Percentag } \\
\text { e }\end{array}$ & $\begin{array}{c}\text { Descriptio } \\
n\end{array}$ \\
\hline $18-20$ & 2 & 1,89 & $\begin{array}{l}\text { Extremely } \\
\text { Disagree }\end{array}$ \\
\hline $21-23$ & 11 & 10,48 & Disagree \\
\hline $24-26$ & 48 & 45,72 & Agree \\
\hline $27-29$ & 37 & 35,24 & $\begin{array}{l}\text { Extremely } \\
\text { Agree }\end{array}$ \\
\hline $30-32$ & 7 & 6,67 & $\begin{array}{l}\text { Very } \\
\text { Extremely } \\
\text { Agree }\end{array}$ \\
\hline & 105 & 100,00 & \\
\hline
\end{tabular}

"Based on table 2, it is revealed that from 105 respondents with 9 rounds of the dimension of reproductive health program, the most respondents were in the 24-26 score range of 48 people $(45.72 \%)$ The respondent stated agree that the development of reproductive health media. In contrast, respondents least or as many as 2 people $(1.89 \%)$ or score range 18-20 rate very disagree. Thus it can be interpreted that special school teachers in Jabodetabek area positively positive about the reproductive health program for students hearing disabilities in special school in Jabodetabek area."

\section{Implementation Dimension of Reproductive Health Learning}

The data presented is data from the score dimension of reproductive health learning implementation from 105 respondents in 14 special schools in Jabodetabek area. The statistics table description can be seen in table 3 .

"Table 3: Frequency distribution Data for reproductive health learning implementation in Special School in JABODETABEK area"

\begin{tabular}{cccl}
\hline $\begin{array}{l}\text { Interva } \\
\text { I Class }\end{array}$ & $\begin{array}{c}\text { Frequenc } \\
\mathbf{y}\end{array}$ & $\begin{array}{c}\text { Percentag } \\
\mathbf{e}\end{array}$ & $\begin{array}{c}\text { Descriptio } \\
\mathbf{n}\end{array}$ \\
\hline $\mathbf{4 0 - \mathbf { 4 6 }}$ & 1 & 0,94 & $\begin{array}{l}\text { Extremely } \\
\text { Disagree } \\
\end{array}$ \\
$\mathbf{4 7 - \mathbf { 5 2 }}$ & 20 & 19,05 & Disagree \\
\hline $\mathbf{5 3 - 5 9}$ & 65 & 61,91 & Agree \\
\hline
\end{tabular}




\begin{tabular}{cccl}
\hline $\mathbf{6 0}-\mathbf{6 6}$ & 16 & 15,24 & $\begin{array}{l}\text { Extremely } \\
\text { Agree }\end{array}$ \\
$\mathbf{6 7 - 7 1}$ & 3 & 2,86 & $\begin{array}{l}\text { Very } \\
\text { Extremely } \\
\text { Agree }\end{array}$ \\
& $\mathbf{1 0 5}$ & $\mathbf{1 0 0}$ & \\
\hline
\end{tabular}

"According to table 3, it is revealed that from 105 respondents with 18 items of the dimension of Reproductive health program, the most results found in the 53-59 score range of 65 people (61.91\%) Respondents stated that they agreed on the implementation of reproductive health learning for hearing impaired students. In contrast, respondents at least or as many as 1 person $(0.94 \%)$ or a score range of 40-46 rate strongly disagree. Thus it can be interpreted that SLB teachers in the Jabodetabek area are largely positive and require the implementation of reproductive health learning for students hearing disabilities in special school in Jabodetabek area."

\section{The Dimension of Reproductive Health Media development}

The data presented is data from the score dimension of reproductive health media development from 105 respondents in 14 special schools in Jabodetabek area. The statistics table description can be seen in the table below.

"Table 4: Data on Media development of reproductive health in Special School JABODETABEK area"

\begin{tabular}{lccl}
\hline $\begin{array}{l}\text { Interva } \\
\text { I Class }\end{array}$ & $\begin{array}{c}\text { Frequenc } \\
\mathbf{y}\end{array}$ & $\begin{array}{c}\text { Percentag } \\
\mathbf{e}\end{array}$ & $\begin{array}{l}\text { Descriptio } \\
\mathbf{n}\end{array}$ \\
\hline $\mathbf{2 1} \mathbf{- 2 6}$ & 0 & 0,00 & $\begin{array}{l}\text { Extremely } \\
\text { Disagree } \\
\end{array}$ \\
$\mathbf{2 7}-\mathbf{3 1}$ & 1 & 0,94 & Disagree \\
\hline $\mathbf{3 2}-\mathbf{3 8}$ & 31 & 29,53 & Agree \\
\hline \hline $\mathbf{3 9}-\mathbf{4 4}$ & 49 & 46,67 & $\begin{array}{l}\text { Extremely } \\
\text { Agree } \\
\end{array}$ \\
$\mathbf{4 5 - 5 0}$ & 24 & 22,86 & $\begin{array}{l}\text { Very } \\
\text { Extremely } \\
\text { Agree }\end{array}$ \\
& & & \\
& $\mathbf{1 0 5}$ & $\mathbf{1 0 0 , 0 0}$ &
\end{tabular}

"Based on table 4, it is revealed that from 105 respondents with 13 items of distribution dimension of reproductive health media development, the most respondents found in the 39- 44 score range of 49 people (46.67\%) Respondents assessed highly agree on the development of reproductive health media for hearing impaired students. Conversely, respondents who do not want the development of the media has the least amount of either the rate of disagreement or strongly disagree there is as much as 1 person $(0.94 \%)$ Or a score range of 27-31. Thus it can be interpreted that special school teachers in the Jabodetabek area positively assess the development of reproductive health media for students with hearing disabilities in the area of Jabodetabek." 


\section{Discussion}

Physically or mentally disabled people are different from the majority. "Teaching students with disabilities presents unique opportunities. Students require interventions that are beyond what is typically available in the General education curriculum [5]. One of the rights they need to get in the education curriculum is related to the communication, information, and education surrounding reproductive health. [23] DomainKeys identified effective strategies for teaching youth with disabilities skills to express sexuality and develop positive relationships (e.g., modeling, guided practice), students with disabilities lack exposure to sexuality education Curricula for various reasons [5] and sometimes, may need specially media learning to support their unique needs." The statement is in accordance with the research results that demonstrate the need for the development of learning media in sex education, one of them on reproductive health.

Education delivery about reproductive health implementation is still considered taboo for Indonesian people in general, but the results of the study said that the education is necessary to be implemented. This becomes very important to give as they grow older and their genital functions grow. As research on media effectiveness for the disabled is said to convey that "Our research indicates that people living with disabilities could benefit from formal, accurate sexual education information and resources. However, the type of information provided and the best media to use needs to be further studied [6]." In this study, the best media development to support the learning of reproductive health for disabled hearing was to use animated media.

Animation Media is one tool that can bridge the limitations of the disabled with disabilities in gaining knowledge about reproductive health. This is confirmed by the results that about 50\% more SLB teachers (especially hearing-impaired educators) welcome or positively look at the material in the form of media animation. The selection of animation media was reinforced by the results of a research that humans process visual information 60,000 times faster than text-based information [16]. In addition, it was strengthened from the Ahmadi study results, that the use of software can help teachers and families of students to provide health education to students with impaired hearing to be able to learn More effectively [1]. Through animated media besides more interesting witnessed also help students with hearing disabilities easier to understand the material delivered.

\section{Conclusion}

How to overcome the limitations while increasing the knowledge of reproductive health in the disabled with hearing impaired, the development of animation-based media can be one solution. Based on the results of the research conducted on 105 special school teachers in the greater Jakarta region, the results welcomed positively to the developed animation media of reproductive health for hearing impaired students. The positive reception will continue with the implementation of learning about reproductive health in hearing impaired students with animated media. With animation-based media, it is expected to eliminate barrier walls in terms of communication, information and education among people with hearing impaired disabilities with teachers, health workers, families, or people close with. related motivation quality, and understanding can be improved.

\section{Suggestion}


Multimedia-based learning materials that are developed need to consider the principles of learning for students with hearing disabilities. The features expected in the animation media are the use of sign language, reading lips, images, animations, and simple and short translation texts; Their healthrelated motivation, quality, and understanding can be improved.

\section{References}

[1] Ahmadi, M., Abbasi, M., \& Bahaadinbeigy, K. (2015). Design and implementation of a software for teaching health related topics to deaf students: The first experience in Iran. Acta Informatica Medica, 23(2),76-80 https://doi.org/10.5455/aim.2015.23.76-80

[2] Anna C. Treacy, Shanon S. Taylor \& Tammy V. Abernathy (2017): Sexual Health Education for Individuals with Disabilities: A Call to Action, American Journal of Sexuality Education, DOI: 10.1080/15546128.2017.1399492

[3] Center for Implementing Technology in Education (CITEd). (n.d.). Multimedia Instruction for Students Who Are Deaf Re-published with permission from American Institutes for Research. Retrieved from http://ctdinstitute.org/sites/default/files/file_attachm ents/CITEd- Multimedia Instruction for Students who are Deaf FINAL.pdf

[4] Chaerizanisazi. (2017). Urgensi Per-UU Kekerasan Seksual Terhadap Difabel. Retrieved June 18, 2019, from http://ciqal.blogspot.com/2017/12/urgensi- per-uu-kekerasan-seksual.html

[5] Dawn A. Rowe, James Sinclair, Kara Hirano \& Josh Barbour (2018) Let's Talk About Sex ... Education, American Journal of Sexuality Education, 13:2, 205- 216, DOI:10.1080/15546128.2018.1457462

[6] Esmail, Shaniff; Darry, Kim; Walter, Ashlea \& Knupp, Heidi. (2010). “Attitudes and perceptions towards disability and sexuality.” Disability and Rehabilitation; 32(14): 1148-1155.

[7] European Expert Group on Sexuality Education (2015): Sexuality education- what is it?, Sex Education, DOI: 10.1080/14681811.2015.1100599

[8] Hidayat, L., Gunarhadi, \& Hidayatulloh, F. (2017). Multimedia Based Learning Materials for Deaf Students. European Journal of Special Education Research,2(3),77-87. https://doi.org/10.5281/zenodo.376744

[9] International Labour Organization. (n.d.). Inklusi Penyandang Disabilitas di Indonesia. Jakarta. Retrieved from https://www.ilo.org/wcmsp5/groups/public/---asia/--ro-bangkok/--ilojakarta/documents/publication/wcms_233426.pdf

[10] Mprah, Wisdom K. (2013). Sexual and reproductivehealth needs assessment with deaf people in Ghana: Methodological challenges and ethical concerns. African Journal of Disability, 2(1), 1-7. https://doi.org/10.4102/ajod.v2i1.55

[11] Mprah, Wisdom Kwadwo. (2015). Perceptions about Barriers to Sexual and Reproductive Health

[12] Information and Services among Deaf People in Ghana. Disability, CBR \& Inclusive Development, 24(3), 21. https://doi.org/10.5463/dcid.v24i3.234

[13] Peraturan Pemerintah RI, Pub. L. No. 61 (2014). Retrieved from http://kesga.kemkes.go.id/images/pedoman/PP No. 61 Th 2014 ttg Kesehatan Reproduksi.pdf

[14] Pusat Data dan Informasi Kesehatan RI. (2014). Penyandang Disabilitas Pada Anak.

[15] Ratna Pertiwi, K. (n.d.). Kesehatan Reproduksi Remaja Dan Permasalahannya. Retrieved from http://staff.uny.ac.id/sites/default/files/tmp/PPM PEER KRR.pdf

[16] Raugust, K. (2006). Teaching the Deaf Through Animation. Retrieved June 19, 2019, from https://www.awn.com/animationworld/teaching- deaf-through-animation

[17] Renu Addlakha, Janet Price \& Shirin Heidari (2017) Disability and sexuality: claiming sexual and reproductive rights, Reproductive Health Matters, 25:50, 4-9, DOI: 10.1080/09688080.2017.1336375

[18] Rokhmah, I., \& Warsiti, W. (2015). Identifikasi Kebutuhan Kesehatan Reproduksi Bagi Remaja Perempuan Difabel (Tuna Grahita) Di Slb Negeri 2 Yogyakarta. Jurnal Kebidanan (Vol. 4). Retrieved 
from https://jurnal.unimus.ac.id/index.php/jur_bid/article /view/1388/1442

[19] Romulo, H. M., Noor Akbar, S., Mayangsari, M. D., Kunci, K., Pengetahuan, :, Reproduksi, K., ... Awal, R. (n.d.). Peranan Pengetahuan Kesehatan Reproduksi Terhadap Perilaku Seksual Remaja Awal (Role Of Reproductive Health Knowledge Towards Early Adolescents' Sexual Behaviors). Retrieved from https://media.neliti.com/media/publications/195897

-ID-peranan-pengetahuan-kesehatan-reproduksi.pdf

[20] Rusinga, O. (2012). Perceptions of deaf youth about their vulnerability to sexual and reproductive health problems in Masvingo District, Zimbabwe. African Journal of Reproductive Health, 16(2), 271282. Retrieved from http://www.ncbi.nlm.nih.gov/pubmed/22916559

[21] Sariyem, Santoso, B., \& Supriyana. (2017). Effectiveness of Animation Media toward Teaching Deaf Students on Dental Hygiene. ARC Journal of Dental Science, 2(4), 2456-2486. https://doi.org/10.20431/2456-0030.0204001

[22] Satria AN. (2013). Hak Reproduksi Difabel Kurang Perhatian. Retrieved June $\quad 18, \quad 2019$, from https://www.ugm.ac.id/id/berita/4843-hak- reproduksi-difabel-kurang-perhatian

[23] Schaafsma, Dilana; Kok, Gerjo; Stoffelen, Joke M. T. \& Curfs, Leopold M. G. (2014): Identifying Effective Methods for Teaching Sex Education to Individuals With Intellectual Disabilities: A Systematic Review, The Journal of Sex Research, DOI: 10.1080/00224499.2014.919373

[24] Sucahyo, N. (2018). Pemaksaan Pemasangan Alat Kontrasepsi Bagi Difabel Tidak Dibenarkan. Retrieved June 18, 2019, from https://www.voaindonesia.com/a/pemaksaanpemasangan-alatkontrasepsi-bagi-difabel-tidakdibenarkan/4230938.html

[25] Sugiyono. (2017). Metode Penelitian Kuantitatif, Kualitatif, dan R\&D. Bandung: Alfabeta.

[26] Undang-Undang Republik Indonesia, Pub. L. No. 8 (2016). Retrieved from http://pugpupr.pu.go.id/_uploads/PP/UU. No. 8 Th. 2016.pdf 